\title{
Dematerialization of banking products and services in the digital era
}

\author{
Shahrazad HADAD \\ The Bucharest University of Economic Studies, Bucharest, Romania \\ The Academy of Romanian Scientist, Bucharest, Romania \\ shahrazad.hadad@fabiz.ase.ro \\ Constantin BRATIANU \\ The Bucharest University of Economic Studies, Bucharest, Romania \\ The Academy of Romanian Scientist, Bucharest, Romania \\ constantin.bratianu@gmail.com
}

\begin{abstract}
The primary purpose of this research is to present the evolution and current state of knowledge regarding the dematerialization of banking products and services in the digital age. The paper discusses the central issues regarding the dematerialization of money, the dematerialization of securities and the dematerialization of the contract, trends with direct impact on the possibility of dematerializing the products and services offered by banking institutions, by means of an investigative discourse and viewpoint into and over the shift from tangible to intangible monetary assets. It mainly explores the impact of dematerialization on certain processes performed by banks (customer enrollment and management) and on certain products and services offered by banks (payment services, lending services, etc.) from the perspective of the latest technological innovations and the influence exerted by fintech companies. The chapter clearly establishes the synergy link between environmental factors (increased competition, technological advance, legislative changes) and the ability of banking institutions to adapt to new conditions by changing the business model. The research ends with a series of conclusions regarding the way in which the tendencies towards dematerialization affect the activity and the business model adopted by the banking institutions. The content of the research report is useful both to the managers in the financial field and to the authorities that legislate this field, especially to those in Romania, who can use the conclusions of the report to elaborate policies in order to advance the degree of digitization of the Romanian banking system.
\end{abstract}

Keywords: cryptocurrency, money dematerialization, fintech, cash, securities, banks.

\section{Introduction}

The idea of a cashless society has been widely promoted and discussed in the last halfcentury and has been presented most often as a solution to many of the problems facing companies today. Although there are several versions of this idea, in essence, all are based on two major premises: the disappearance of the cash and the role played in this disappearance by the reorientation towards the technological solutions that allow the dematerialization of the money. The project of complete dematerialization of money continues today, but it remains difficult to implement because there are conflicting interests and motivations, besides the technical problems that have not yet found fully satisfactory solutions. Moreover, the tendency to eliminate cash and introduce electronic payment 
methods raises two questions that do not have an easy answer: What is cash? What do we really mean by the materiality of money?

According to the definition in the Romanian explanatory dictionary, cash is a "money value in coins or paper money, which can be used directly for payment" and is also known as liquid money or ice money. Over time, the definition of cash has become more nuanced, encompassing "their money or signs, in their physical form of banknotes, treasury bills, metallic currency, and divisional currency" (DEX online, 2019). The word comes from the Latin language, from the term numerarius, which has two definitions: arithmetician and accountant, account manager. It is obvious that the definition of cash, initially based on the idea of a good of value that can be stored and manipulated, has progressively evolved to acquire new meanings that are logically associated with the ability of a debtor to pay his debt on the spot. A second important feature is the anonymity of the transactions. Thirdly, such a means of payment is essentially manual, so material, which makes it relatively incompatible with the functional definition of money (for example, means of payment, means of closing debts, a reserve of value). At the same time, the fact that the meaning of the word cash has expanded over time through the inclusion of tickets and other immediate means of payment reflects the change in the nature of money over the last centuries. Thus, cash has also come to include certain forms of fiduciary currency, ie, money without an intrinsic value given by their materiality (such as modern banknotes). Unlike gold, shells or silver that were used in the past as money, today's cash is far from being material in the true sense of the word because its value is given by the guarantees offered by the issuing authority, not by its material nature. Thus, today's cash is an additional form of money whose main quality is given by the fact that it allows the transactions to be concluded anonymously and on the spot, at the debtor's convenience (Weatherford, 1998). We can even say that in developed companies, cash has become the small commodity used for small volume transactions, given that important (high value) transactions are generally concluded by other means of payment.

\section{Money dematerialization}

It is clear that it is costly to issue material means of payment and that these costs are the main reason that led to the emergence of dematerialized means of payment, but before we can understand the tendency towards dematerialization it is necessary to understand why, initially, the money was material. The main reason is related to the intention to combat counterfeiting and to the difference between the cost involved in issuing banknotes or coins and their actual value, known as seniority (Ferguson, 2009). Seniority designates the party that has to win in the case of systems based on the issuance of fiduciary cash, the part that can be the state, a bank, or a trader. Essentially, seniority represents the added value of trust costs over issuance costs and is based either on tradition or trust, representing the main reason why the first coins appeared in the 6th century BC. in Lydia (a kingdom of Asia Minor) (Ferguson, 2009). But the development of the first silver coins in Asia Minor created fierce competition between the city-states that reduced the seniority to a minimum, the silver drachmas finally containing a very large amount of silver. Only in the case of a monopoly (as in the case of the Roman Empire) was it possible to increase seniority (Ferguson, 2009). This motivates us to look carefully at the difference between currencies (the classic 
representative of cash) and banknotes (the classic representative on credit). For example, almost throughout the nineteenth century, although there were obvious means of payment on the spot, banknotes were not seen as the cash equivalent. In France, any creditor could refuse payment by banknotes, at least until 1870, regardless of the amount owed (Weatherford, 1998). In England, the legal payment value of silver coins was established in 1914 at two pounds, and that of bronze coins at a shilling, and cash payment referred to payments made through coins (Weatherford, 1998). The examples provided above demonstrate that cash, though it clearly refers to a method of payment on the spot, is not a specific term: worlds, shells, banknotes and even deposits can be, successively or alternatively, considered as cash by at least a part of the holders.

Thus, we came to a definition of cash. On the one hand, until the 19th century, cash was made up of material objects that had a conventional or legal value attached. These objects were manually transferred and could be transferred anonymously. Regardless of their legal value, they also had a market value either due to content or other conventions, and governments generally had to contend with the tendency of citizens to keep cash in the form of gold, silver or bronze for use in non-monetary purposes (Ferguson, 2009). In essence, cash was a legal or conventional means of payment that could be used to pay off debts (anonymously or not) on the spot.

To answer the question of what dematerialization means, it is necessary to determine whether cash was a form of money or whether it was only a certain form of money. First, both cash and money, in general, derive their value from a set of properties such as conventions, rules, fiscal status, legal means of payment, and the value is either intrinsic, religious, specific to certain transactions, aesthetic or practical. Secondly, the distinction between cash and money implies an evaluation rule that is usually related to the existence of a legal system and a state, meant to impose a generally valid monetary account unit. For long periods of time, the connection between the unit of account and cash was relatively unstable and subject to changes in market value and the legal system, which is far from the idea of stable monetary value (Weatherford, 1998). Third, anonymity plays an important role in the case of cash, which, although not used in all transactions, always allows anonymization of the parties involved in the transaction in relation to the issuer or the state. Banknotes became cash in Europe when confidence increased not only because they were permanently used, but also because there were no viable cash alternatives (as was the case in Sweden) and only later due to legal changes (Ferguson, 2009). Thus, it becomes obvious that money and cash are complementary things and that, viewed as a monetary system, money cannot be dematerialized because they already represent a principle, an abstract concept. Consequently, only cash itself can be dematerialized, as a result of the desire to reduce its weight (which may prove inapplicable in practice), to increase seniority, to avoid trading costs and other expenses, etc.

In general, there are three major types of cash dematerialization: collateralization, inflation, and innovation (Baubeau, 2016). First, cash can be dematerialized when it is used as collateral for a new currency. This process can be applied either to new forms of cash or to the conversion of illiquid assets into cash. Second, innovation applies to cash in the same way as it applies to any device: new techniques and new forms will make their way to the 
citizens' pocket even if it is necessary to circumvent state authority (a clear example being provided by cryptocurrencies). Thirdly, dematerialization can be linked to the activity of the state which, unable to declare its bankruptcy, tends to issue new currencies in order to cover its debts, thus generating inflation. In general, inflation was also associated with a dematerialization of cash because expensive forms (gold, silver) were replaced by less expensive forms (e.g., paper).

The first dematerialized money appeared in the early 1980s due to the increased use of pre-paid cards in the telephony industry. At present, there are three major types of dematerialized money: electronic money, virtual money, and digital money (Pîrjan and Petroșanu, 2008). The economic value of electronic money is measured in units of trust currency that are stored in electronic form on an electronic device available to the consumer. Electronic money is the digital version of scriptural money that is stored on a smartcard or mobile device. Virtual money does not have an equivalent in tangible forms of payment, this being the main aspect that differentiates them from electronic money. Virtual money is stored in software applications that allow transactions through the Internet. Dematerialization of money is a part of a larger process of digitalization and emergence of intangibles (Bratianu, 2018) as strategic resources of any organization. Knowledge in its rational, emotional, and spiritual forms becomes the kernel of any economic process (Bratianu \& Bejinaru, 2019; Bratianu \& Orzea, 2013), and it challenges our mindset on tangibility and linearity.

All transactions that use money in various stages of dematerialization can be compared to transactions that use cash based on the following criteria (see Table 1):

a) atomicity: in order to have consequences, a transaction must complete all stages. If this does not happen, then it is necessary to be able to return to the state before the transaction is initiated.

b) consistency: all parties involved in the transaction must accept the nature and purpose of the transaction.

c) isolation: each transaction must be unique and not interfere with other transactions.

d) anonymity: the disclosure of the identity of the buyer is not necessary to pay the obligations. On the other hand, personalization involves knowing the identity of the buyer in order to be able to personalize the offer.

e) non-traceability: besides anonymity, this property reflects the fact that it should not be possible to connect two payments made by the same person.

Table 1. Properties of various forms of dematerialized money

\begin{tabular}{|l|l|l|l|l|l|l|l|l|}
\hline \multicolumn{1}{|c|}{ Property } & Cash & Cheque & $\begin{array}{c}\text { Bank } \\
\text { transfer }\end{array}$ & $\begin{array}{c}\text { Direct } \\
\text { debit }\end{array}$ & $\begin{array}{c}\text { Debit } \\
\text { card }\end{array}$ & $\begin{array}{c}\text { Credit } \\
\text { card }\end{array}$ & $\begin{array}{c}\text { Electronic } \\
\text { money }\end{array}$ & $\begin{array}{c}\text { Virtual } \\
\text { money }\end{array}$ \\
\hline Atomicity & Yes & Yes & Yes & Yes & Yes & Yes & Yes & Yes \\
\hline Consistency & Yes & Yes & Yes & Yes & Yes & Yes & Yes & Yes \\
\hline Isolation & Yes & Yes & Yes & Yes & Yes & Yes & Yes & Yes \\
\hline Anonymity & Yes & No & No & No & No & No & Possible & Possible \\
\hline $\begin{array}{l}\text { Non- } \\
\text { traceability }\end{array}$ & Yes & No & No & No & No & No & Possible & Possible \\
\hline
\end{tabular}

Source: Pîrjan and Petrosanu (2008). 
As can be seen from Table 1, only cash fulfills all five properties, which explains, at least in part, why cash is still widely used for payments. This fact is also evidenced by the statistics regarding the amount of euro banknotes currently in circulation displayed in Figure 1. Between 2002 and 2019, the total quantity of euro banknotes in circulation increased from 7,798,512,744 banknotes to 22,562,930,215, indicating an average annual growth rate of $6.4 \%$. This increase in the monetary mass in circulation was due in large part to the demand for 50 euro banknotes. During the same period, the total amount of banknotes of 50 euros increased from 1,417,053,560 banknotes to 10,520,579,786 banknotes, indicating an average annual growth rate of $12.5 \%$. A similar increase was also recorded in the case of currencies, the total amount of euro coins increasing from 38,077,886,783 in January 2002 to 132.22.051.711 in May 2019, which indicates an average annual growth of 7.6\% ("Banknotes and Coins Circulation", 2019). Although these figures indicate widespread use of cash, it should also be noted that part of this increase in the money supply was also due to the expansion of the euro area in several stages. Slovenia joined the euro area in 2007, Cyprus and Malta in 2008, Slovakia in 2009, Estonia in 2011, Latvia in 2014 and Lithuania in 2015. However, the number of banknotes in circulation has grown steadily, even after 2015, a fact which indicates the popularity of cash in commercial transactions within the territory of the Member States of the European Union. 


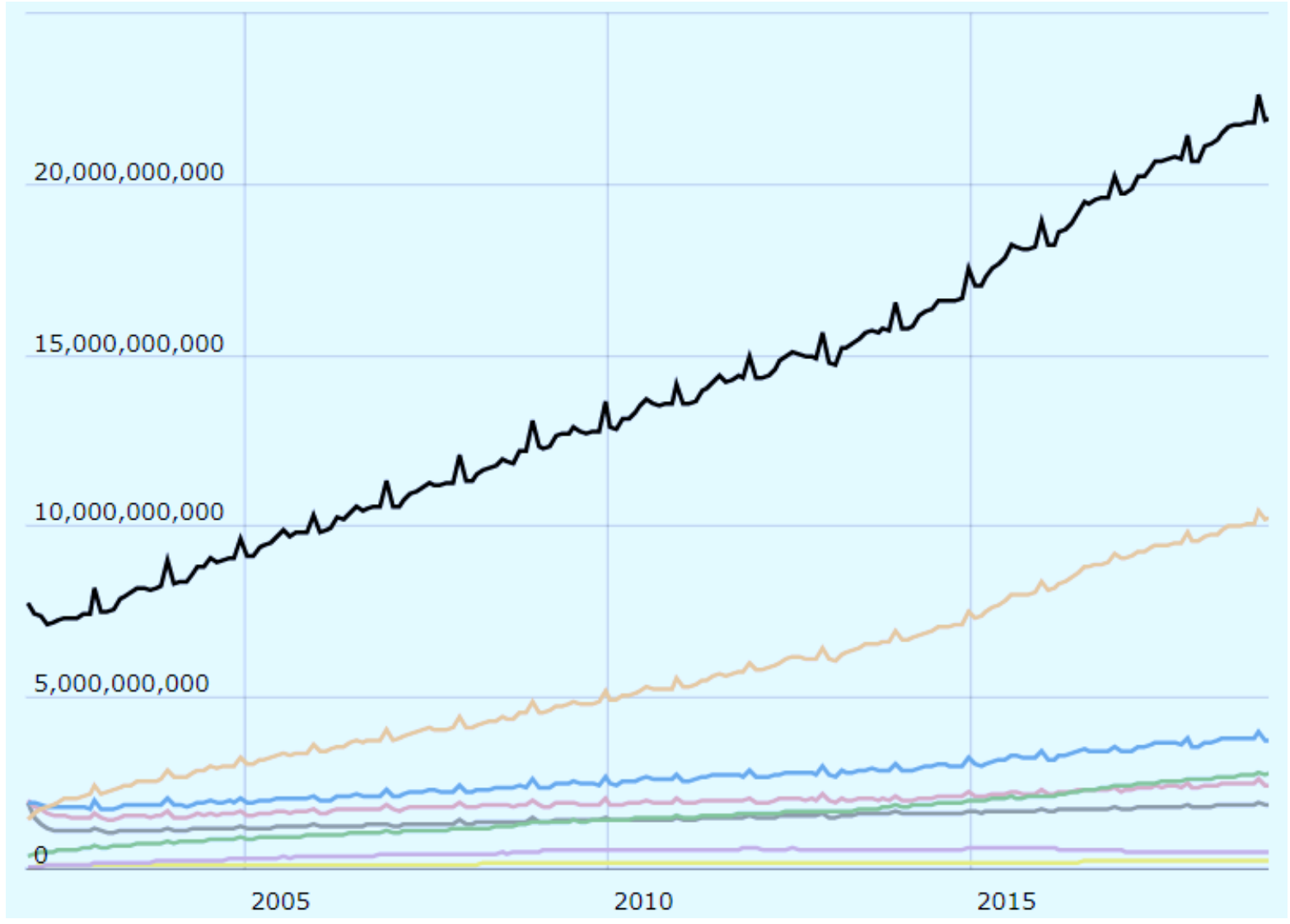

Figure 1. Statistics on euro banknotes in circulation between January 2002 and February 2019

Notes: black - the total quantity of banknotes, orange - the amount of banknotes of 50 euros, blue banknotes of 20 euros, pink - banknotes of 10 euros, green - banknotes of 100 euros, yellow - banknotes of 200 euros, purple - 500 euro banknotes. Source: European Central Bank (2019).

It is obvious that innovation is now the main driver of the dematerialization of cash and the main reason why many imagine a society where there is no cash. The main innovation trend is currently focusing on the development of digital techniques for recording transactions and debiting accounts. The Internet has transformed transactions, especially in developed countries where citizens can use alternative forms of cash such as cryptocurrencies, virtual wallets, and more. But in what sense can we really speak of dematerialization of payments? In fact, when natural disasters occur, and there is no longer access to electricity, cash (ie, coins and banknotes) performs their functions of payment means much better than any virtual payment system. It is obvious that the virtual is not completely disconnected from the material and that behind the electronic or virtual money is a huge network of computers, thousands of kilometers of fiber optic or copper cable, digital device manufacturers, a multitude of engineers and authorities which oversee the entire activity of the system. In essence, the success of dematerialized money is also based on material factors, that is, on traditional infrastructures. It can be concluded that no matter how virtual the money becomes in the future, they will still depend on the operation of 
tangible equipment and costly know-how. So, how is a virtual payment system different from a cash-based system? Not by the nature of the infrastructure used, but by the magnitude: current payment systems record billions of daily transactions, a number likely to be missed by old payment systems.

At this point, we can ask ourselves one last question: Can virtual money be considered cash? As we have shown above, they lack an essential quality of cash - anonymity, which derives from the possibility of objectifying cash. Most digital payment systems require the identification of both the buyer and seller either directly (name, account number, etc.) or indirectly (IP address). The only alternative that seems to promise anonymity is cryptocurrencies, but they have a controversial legal status at the moment, and it is clear that their transformation into legal means of payment will directly affect the anonymity of the parties involved in transactions. This should remind us of the true costs of a cashless company, a company in which all payments and transfers are recorded and can be tracked either by the state or by any other organization, leading to a company based on supervision.

\section{Dematerialization of securities}

Electronic transactions in the capital markets began in the early 1960s with the invention of the first digital pricing system that marked the transition from traditional systems based on shouting, the telephone or telegraph transactions, to automated systems based on electronic means of communication. (DTCC, 2012). One of the first providers of digital systems to provide stock exchange information was New York-based Scantlin Electronics (Dubovec, 2014). Brokers who were subscribed to the services of this company could have access to stock information through a telephone internet connection. In 1969, Instinet introduced the first automatic securities trading system in the US, which allowed institutional investors to trade pink securities without intermediaries, in a similar way in which the shares of listed companies were traded (Dubovec, 2014). Since the 1980s, most of the world's stock exchanges have already begun to develop their own systems for transaction automation. The Tokyo Stock Exchange introduced electronic trading in 2003, NASDAQ in 1971, the New York Stock Exchange in 2014, and currently all stock exchanges offer the ability to trade electronically. Electronic trading was seen as a positive transformation of capital markets because it increased liquidity, decreased fees, and taxes and increased market access for investors (DTCC, 2012).

For companies listed on the stock exchange, using paper stocks is very cumbersome, which explains why most of these companies work with electronic securities. In contrast, companies on shares that are not listed on the stock exchange, the use of dematerialized securities is far too complex and too expensive because of the fees that must be paid to the banks. As a result, most such companies still use paper certificates. In most jurisdictions that allow the trading of dematerialized securities, there is a central settlement house or a limited number of such institutions that have been authorized by public authorities to perform these functions. The final shareholder usually holds the securities in an account opened at a bank or brokerage firm, which in turn has an account open at the central settlement house. Sometimes, the foreign settlement houses also have open accounts at the central settlement 
house in the country where the company issued its shares. More complex intermediary chains are also possible.

According to the data in Table 2, at the level of the European Union stock exchanges, in the period 2016-2018, the number of electronic transactions increased on average by $22 \%$ per year, and the total volume of electronic transactions increased on average by $19.3 \%$ per year. In terms of the number of transactions, the highest growth rates were recorded for the Hungarian stock exchange (11.5\%), the Swiss stock exchange $(13.2 \%)$, the Norwegian stock market (17.1\%) and the Aquis Exchange stock market. (67.2\%), the pan-European independent company based in London. At the level of total trading volume, the highest growth rates were recorded for the Norwegian stock exchange $12.4 \%)$ the Romanian stock exchange (14\%), the German stock market (14\%) and the Aquis Exchange stock market $(56.5 \%)$.

Table 2. Statistics on electronic transactions in EU capital markets

\begin{tabular}{|c|c|c|c|c|c|c|c|c|}
\hline \multirow[b]{2}{*}{ Market operator } & \multicolumn{2}{|c|}{2018} & \multicolumn{2}{|c|}{2017} & \multicolumn{2}{|c|}{2016} & \multicolumn{2}{|c|}{ CAGR16-18 (\%) } \\
\hline & Transactions & $\begin{array}{c}\text { Volume } \\
\text { (mil. Euro) }\end{array}$ & Transactions & $\begin{array}{c}\text { Volume } \\
\text { (mil. Euro) }\end{array}$ & Transactions & $\begin{array}{c}\text { Volume } \\
\text { (mil. Euro) }\end{array}$ & Transactions & Volume \\
\hline $\begin{array}{c}\text { Athens } \\
\text { Exchange }\end{array}$ & 4997273 & 10774,5 & 4329400 & 11387,1 & 4639181 & 12879,1 & 3,8 & -8.5 \\
\hline BME & 44027990 & 548576,7 & 50726794 & 619121,2 & 54135347 & 618930 & $-9,8$ & $-5,9$ \\
\hline Boerse Stuttgart & 1647235 & 16192,1 & 1668538 & 18310,2 & 1392773 & 16859,7 & 8,8 & -2 \\
\hline $\begin{array}{l}\text { Bucharest Stock } \\
\text { Exchange }\end{array}$ & 534245 & 2132,7 & 797687 & 2006,1 & 650161 & 1640,9 & $-9,4$ & 14 \\
\hline $\begin{array}{l}\text { Budapest Stock } \\
\text { Exchange }\end{array}$ & 1675559 & 8673,7 & 1743560 & 8688 & 1346828 & 7347,5 & 11,5 & 8,7 \\
\hline $\begin{array}{l}\text { Bulgarian Stock } \\
\text { Exchange }\end{array}$ & 49322 & 183,7 & 75636 & 315,7 & 53936 & 176,3 & $-4,4$ & 2,1 \\
\hline CEESEG - Prague & 705619 & 5551,4 & 776574 & 5269,4 & 895979 & 6213,2 & $-11,3$ & $-5,5$ \\
\hline CEESEG - Vienna & 5565691 & 35220,1 & 6766881 & 33376,9 & 6625672 & 27975,7 & $-8,3$ & 12,2 \\
\hline $\begin{array}{c}\text { Cyprus Stock } \\
\text { Exchange }\end{array}$ & 24238 & 48,7 & 26533 & 57,7 & 31893 & 78,2 & $-12,8$ & $-21,1$ \\
\hline Deutsche Börse & 133379663 & 1538059,9 & 140309311 & 1300956,4 & 137827209 & 1184365,5 & $-1,6$ & 14 \\
\hline Equiduct & 6302306 & 41896,4 & 8155569 & 50366,6 & 10071313 & 57041,2 & $-20,9$ & $-14,3$ \\
\hline Euronext & 224413457 & 1864832 & 234549334 & 1707503 & 222889417 & 1601434 & 0,3 & 7,9 \\
\hline $\begin{array}{l}\text { Irish Stock } \\
\text { Exchange }\end{array}$ & 3681557 & 28063,3 & 3208095 & 24142,8 & 3217679 & 23543,2 & 7 & 9,2 \\
\hline Ljubljana SE & 30286.335 & 327,682 & 49189 & 334,5 & 81629 & 322,2 & $-39,1$ & 0,9 \\
\hline LSE Group & 340371000 & 2142651 & 326186000 & 2051513 & 322394903 & 2070377,9 & 2,8 & 1,7 \\
\hline $\begin{array}{l}\text { Luxembourg } \\
\text { Stock Exchange }\end{array}$ & 7786 & 81,6 & 10,129 & 78,2 & 9006 & 74 & -7 & 5 \\
\hline $\begin{array}{c}\text { Malta Stock } \\
\text { Exchange }\end{array}$ & 10401 & 86,2 & 10,249 & 88 & 10092 & 77,8 & 1,5 & 5,3 \\
\hline $\begin{array}{l}\text { Nasdaq Nordics } \\
\text { \& Baltics }\end{array}$ & 152687281 & 718564,9 & 135534625 & 704425,3 & 115437788 & 643951,1 & 15 & 5,6 \\
\hline Oslo Børs & 31436761 & 123861,2 & 24573226 & 103311,8 & 22908399 & 98041,5 & 17,1 & 12.4 \\
\hline $\begin{array}{l}\text { SIX Swiss } \\
\text { Exchange } \\
\end{array}$ & 57250643 & 814829,6 & 48273205 & 835178,5 & 44668529 & 782500,6 & 13,2 & 2 \\
\hline $\begin{array}{l}\text { Warsaw Stock } \\
\text { Exchange }\end{array}$ & 18807486 & 48310,7 & $20,888,240$ & 55819,4 & 18433081 & 43664,8 & 1 & 5,2 \\
\hline TASE & 15203796 & 55181 & 15566299 & 59016 & 12440273 & 47297,5 & 10,6 & 8,0 \\
\hline Aquis Exchange & 48731116 & 258947,6 & 29950776 & 168355,2 & 17435889 & 105704,1 & 67,2 & 56.5 \\
\hline Turquoise & 147314485 & 621097 & 195764176 & 809669,0 & 288275651 & 1223924 & $-28,5$ & $-28,8$ \\
\hline
\end{tabular}


According to Table 3, at the level of the European Union, the number of non-electronic transactions on the capital markets increased by only $2.3 \%$ in the period 2016-2018, while the volumes traded increased by $35.7 \%$. The total value of non-electronic transactions in 2018 represents only one fifth of the value of electronic transactions, which demonstrates a marked tendency towards complete dematerialization of financial instruments traded on capital markets. This trend is also demonstrated by the fact that only a part of the market operators also carries out non-electronic transactions, $34 \%$ of the operators who provided data to the EFF in 2018 reporting the non-electronic transactions. In the case of the Bucharest Stock Exchange, the number of non-electronic transactions decreased on average by $50.8 \%$ per year, and the volume by $72.8 \%$ per year in $2016-2018$.

At the European Union level, both forms of actions are still accepted: paper certificates or dematerialized form. Dematerialized securities are defined as securities that are created and deposited in an electronic securities account opened at a financial institution. Traditionally, shares are represented by paper certificates, especially in the case of bearer shares. Even in the case of registered actions, some Member States issue paper certificates, but even if these certificates are issued, they do not incorporate the rights arising from the registered actions. The certificate, in this case, functions as a bank account statement that indicates that a particular client has a sum of money in the account: the transfer of the paper certificate does not imply the transfer of the ownership rights over registered shares. Thus, the registered action is, in fact, immaterial. Theoretically, it could be dematerialized if, together with the names entered in the stock register, it would be possible to create shares in a securities account. These actions could then be transferred from one account to another only by changing the registry.

Table 3. Statistics on non-electronic transactions on EU capital markets

\begin{tabular}{|l|c|c|c|c|c|c|c|c|}
\hline \multirow{2}{*}{$\begin{array}{l}\text { Market } \\
\text { operator }\end{array}$} & $\begin{array}{c}\text { Transacti } \\
\text { ons }\end{array}$ & $\begin{array}{c}\text { Volume } \\
\text { (mil. Euro) }\end{array}$ & $\begin{array}{c}\text { Transactio } \\
\text { ns }\end{array}$ & $\begin{array}{c}\text { Volume } \\
\text { (mil. } \\
\text { Euro) }\end{array}$ & $\begin{array}{c}\text { Transacti } \\
\text { ons }\end{array}$ & $\begin{array}{c}\text { Volume } \\
\text { (mil. Euro) }\end{array}$ & $\begin{array}{c}\text { Transactio } \\
\text { ns }\end{array}$ & $\begin{array}{c}\text { Volum } \\
\text { e }\end{array}$ \\
\hline $\begin{array}{l}\text { Athens } \\
\text { Exchange }\end{array}$ & 1713 & 2427 & 1715 & 1566,8 & 1663 & 2040,6 & 1,5 & 9 \\
\hline BME & 110899 & 36041,2 & 119925 & 28248,2 & 147390 & 27583,8 & $-13,2$ & 14.3 \\
\hline $\begin{array}{l}\text { Boerse } \\
\text { Stuttgart }\end{array}$ & $\mathrm{n} / \mathrm{a}$ & $\mathrm{n} / \mathrm{a}$ & $\mathrm{n} / \mathrm{a}$ & $\mathrm{n} / \mathrm{a}$ & $\mathrm{n} / \mathrm{a}$ & $\mathrm{n} / \mathrm{a}$ & $\mathrm{n} / \mathrm{a}$ & $\mathrm{n} / \mathrm{a}$ \\
\hline $\begin{array}{l}\text { Bucharest } \\
\text { Stock } \\
\text { Exchange }\end{array}$ & 339 & 284,6 & $\mathrm{n} / \mathrm{a}$ & $\mathrm{n} / \mathrm{a}$ & 1400 & 3853,7 & $-50,8$ & $-72,8$ \\
\hline $\begin{array}{l}\text { Budapest } \\
\text { Stock } \\
\text { Exchange }\end{array}$ & 124 & 56.8 & 555 & 326 & 594 & 372 & $-54,3$ & $-60,9$ \\
\hline $\begin{array}{l}\text { Bulgarian } \\
\text { Stock } \\
\text { Exchange }\end{array}$ & 6 & 1.6 & 10 & 6.4 & 25 & 20.1 & -51 & $-71,8$ \\
\hline $\begin{array}{l}\text { Cboe } \\
\text { Europe } \\
\text { Equities }\end{array}$ & 10976793 & 1335010,1 & $\mathrm{n} / \mathrm{a}$ & $\mathrm{n} / \mathrm{a}$ & 0 & & 0 & $\mathrm{n} / \mathrm{a}$ \\
\hline $\begin{array}{l}\text { CEESEG - } \\
\text { Prague }\end{array}$ & $\mathrm{n} / \mathrm{a}$ & $\mathrm{n} / \mathrm{a}$ & 11656118 & 618534,1 & 0 & & 0 & $\mathrm{n} / \mathrm{n}$ \\
\hline
\end{tabular}




\begin{tabular}{|c|c|c|c|c|c|c|c|c|}
\hline $\begin{array}{l}\text { CEESEG - } \\
\text { Vienna }\end{array}$ & $\mathrm{n} / \mathrm{a}$ & $\mathrm{n} / \mathrm{a}$ & $\mathrm{n} / \mathrm{a}$ & $\mathrm{n} / \mathrm{a}$ & 0 & 0 & $\mathrm{n} / \mathrm{a}$ & $\mathrm{n} / \mathrm{a}$ \\
\hline $\begin{array}{l}\text { Cyprus } \\
\text { Stock } \\
\text { Exchange }\end{array}$ & 115 & 46 & $\mathrm{n} / \mathrm{a}$ & $\mathrm{n} / \mathrm{a}$ & 71 & 18,6 & 27,3 & 57,3 \\
\hline $\begin{array}{l}\text { Deutsche } \\
\text { Börse }\end{array}$ & 796325 & 33026,2 & 45 & 17.8 & 189230 & 16156,1 & 105,1 & 43 \\
\hline Equiduct & $\mathrm{n} / \mathrm{a}$ & $\mathrm{n} / \mathrm{a}$ & 281707 & 18337,7 & 11815 & 129,7 & $\mathrm{n} / \mathrm{a}$ & $\mathrm{n} / \mathrm{a}$ \\
\hline Euronext & 185067 & 45205 & 12997 & 147,6 & 144073 & 31997 & 13,3 & 18,9 \\
\hline $\begin{array}{l}\text { Irish Stock } \\
\text { Exchange }\end{array}$ & 68091 & 20986,8 & 166268 & 49532 & 72807 & 21191,3 & $-3,3$ & $-0,5$ \\
\hline Ljubljana SE & $\mathrm{n} / \mathrm{a}$ & $\mathrm{n} / \mathrm{a}$ & 70603 & 25022 & 0 & 0 & $\mathrm{n} / \mathrm{a}$ & $\mathrm{n} / \mathrm{a}$ \\
\hline $\begin{array}{l}\text { London } \\
\text { Stock } \\
\text { Exchange } \\
\text { Group }\end{array}$ & 15010000 & 779839 & $\mathrm{n} / \mathrm{a}$ & $\mathrm{n} / \mathrm{a}$ & 24199244 & 1073177,8 & $-21,2$ & $-14,8$ \\
\hline $\begin{array}{l}\text { Luxembour } \\
\text { g Stock } \\
\text { Exchange } \\
\end{array}$ & $\mathrm{n} / \mathrm{a}$ & $\mathrm{n} / \mathrm{a}$ & 29319000 & 1634417 & $\mathrm{n} / \mathrm{a}$ & $\mathrm{n} / \mathrm{a}$ & $\mathrm{n} / \mathrm{a}$ & $\mathrm{n} / \mathrm{a}$ \\
\hline $\begin{array}{l}\text { Malta Stock } \\
\text { Exchange }\end{array}$ & $\mathrm{n} / \mathrm{a}$ & $\mathrm{n} / \mathrm{a}$ & $\mathrm{n} / \mathrm{a}$ & $\mathrm{n} / \mathrm{a}$ & $\mathrm{n} / \mathrm{a}$ & $\mathrm{n} / \mathrm{a}$ & $\mathrm{n} / \mathrm{a}$ & $\mathrm{n} / \mathrm{a}$ \\
\hline $\begin{array}{l}\text { Nasdaq } \\
\text { Nordics \& } \\
\text { Baltics } \\
\end{array}$ & 74082 & 49438,2 & 0 & 0.0 & 1257076 & 62840,7 & $-75,7$ & $-11,3$ \\
\hline Oslo Børs & 17456 & 12050,2 & 1143540 & 67168,8 & 39268 & 10221,1 & $-33,3$ & 8,6 \\
\hline $\begin{array}{l}\text { SIX Swiss } \\
\text { Exchange }\end{array}$ & 1900 & 5547,1 & 52300 & $12,771.3$ & 2046 & 6666,9 & $-3,6$ & $-8,8$ \\
\hline $\begin{array}{l}\text { Warsaw } \\
\text { Stock } \\
\text { Exchange }\end{array}$ & 1887 & 2642,8 & 2139 & 7576,1 & 3288 & 4304,1 & $-24,2$ & $-21,6$ \\
\hline $\begin{array}{l}\text { Zagreb } \\
\text { Stock } \\
\text { Exchange }\end{array}$ & 111 & 73,2 & 2384 & 7482,5 & $\mathrm{n} / \mathrm{a}$ & $\mathrm{n} / \mathrm{a}$ & $\mathrm{n} / \mathrm{a}$ & $\mathrm{n} / \mathrm{a}$ \\
\hline TASE & 94485 & 9711 & 92827 & 7664 & 70382 & 6295,1 & 15,9 & 24,2 \\
\hline $\begin{array}{l}\text { Aquis } \\
\text { Exchange }\end{array}$ & $\mathrm{n} / \mathrm{a}$ & $\mathrm{n} / \mathrm{a}$ & $\mathrm{n} / \mathrm{a}$ & $\mathrm{n} / \mathrm{a}$ & $\mathrm{n} / \mathrm{a}$ & $\mathrm{n} / \mathrm{a}$ & $\mathrm{n} / \mathrm{a}$ & $\mathrm{n} / \mathrm{a}$ \\
\hline Turquoise & $\mathrm{n} / \mathrm{a}$ & $\mathrm{n} / \mathrm{a}$ & $\mathrm{n} / \mathrm{a}$ & $\mathrm{n} / \mathrm{a}$ & $\mathrm{n} / \mathrm{a}$ & $\mathrm{n} / \mathrm{a}$ & $\mathrm{n} / \mathrm{a}$ & $\mathrm{n} / \mathrm{a}$ \\
\hline Total & 27339393 & 2332386.8 & 42922133 & $\begin{array}{c}2478818 \\
3\end{array}$ & 26140372 & 1266868,6 & 2,3 & 35,7 \\
\hline
\end{tabular}

Dematerialization of securities and electronic transactions are closely linked to many of the factors affecting the number of market operators. On the one hand, dematerialization can lead to an increase in the number of traders by making existing stock markets able to compete with new markets that enjoy lower start-up costs and the ability to specialize in trading certain securities. On the other hand, electronic trading systems can create links to combine multiple sources of liquidity and increase their efficiency, leading to market consolidation. In addition to this, the speed of development of the technologies used to create these systems is constantly accelerating the trend of change. In general, these two effects are characteristic of a dynamic market where entry opportunities for new market players initially lead to the fragmentation that is followed by a consolidation when certain market players reach a dominant position from which they can enjoy network effects (Allen, Hawkins \& Sato, 2001). The strong influence of network effects means that the proliferation of similar trading systems that manage to attract small volumes of liquidity is only a transient phenomenon. In fact, those systems that succeed in imposing themselves are based not only on the fact that they offer certain advantages but also on the fact that they manage to attract and retain a sufficient volume of liquidity. This is clearly visible in the markets where shares are traded, which are largely dominated by centralized (national) stock exchanges, but which 
are now in a process of consolidation due to the fact that pan-European markets have emerged such as Aquis Exchange that managed to attract an increasing volume of transactions (see Table 1.8).

Dematerialization of securities may increase access to trading systems through several effects. For example, the physical limitations that affected trading on the stock exchanges by shouting are no longer relevant in this case, which makes it possible for more agents to gain access to the stock markets. Moreover, the fact that transactions can now be done remotely eliminates geographical limitations, which increases the number of potential investors who can be attracted to either existing or newly formed markets. On the other hand, the legislative limitations are becoming much more important in the context of the dematerialization of the securities, especially with regard to transactions outside the borders of the country of residence. Moreover, access to capital markets is now also limited by technological availability (for example, the degree of Internet penetration among the population, the speed of Internet services that may limit access to intra-day markets, etc.). The dematerialization of the securities facilitated the access to the capital markets and by reducing the dependency of intermediaries if we consider that now the investors can trade directly on different platforms without requiring the intervention of a broker.

The benefits of the dematerialization of securities for investors are the following: a) time savings because for the electronic execution of transactions it is neither necessary to create paper documents nor to visit the brokers; b) increasing the speed and safety of transactions because it eliminates the inefficiencies due to delays in clearing and delivery; c) ability to monitor securities at any time and from anywhere, which can increase the profit through greater participation and attention paid by investors to trading activity; d) increased control over transactions, given that each transaction must be authorized by the investor; e) reducing the risk of losing the securities as a result of theft, fires, floods or earthquakes; f) reducing brokerage commissions and increasing liquidity; g) reducing the risk of losing the securities as a result of a defective delivery.

The benefits of dematerializing the securities for the listed companies are as follows: a) issuing electronic securities allows to maintain a more efficient trading system by quickly transferring the securities; b) reducing the costs of issuing securities because it is no longer necessary to print paper shares and distribute them to investors; c) increasing the efficiency of agents dealing with securities trading on capital markets; d) ability to communicate much more efficiently and quickly with investors.

The benefits of dematerializing securities for brokers are as follows: a) the possibility to provide more quality services because there is a limited risk of fraud, theft or missed deliveries; b) higher profits resulting from increased volumes traded; c) the elimination of the risks regarding the falsification of the securities or their defective delivery; d) increasing the efficiency of trading, profitability and investor confidence. In addition to these many benefits, it should be mentioned that the dematerialization of the securities is generally associated with a number of disadvantages such as a higher degree of volatility in the capital markets, the increased possibility of influencing the behavior of investors through rapid movements on the stock exchanges by certain investors and a general increase in the vulnerability of the markets that results from the inability of the authorities to monitor the 
trading activity. Most of these disadvantages are associated with the proliferation of automated trading which includes numerous risks such as: a) encouraging market manipulation strategies (for example, spoofing, the use of washing transactions, stratifying orders, etc.); b) flooding the system with trading orders as a result of algorithm errors; c) the risk that an investor will signal his intention to carry out a risky transaction that can lead to what is called a flash crash (a sharp drop in the value of the securities) due to the fact that so many investors follow the agent's example; d) increasing the possibility of applying frontrunning practices (the abusive practice whereby an agent uses the information obtained from customer relations to transact on their own behalf and obtain benefits from this information); e) a decrease in the real liquidity of the market (Sachee, 2016).

The situation regarding paper actions in the European Union is currently uncertain. The exit of Britain from the EU has led to heated discussions about how such actions could be traded across the EU, given that Ireland and the United Kingdom are the only two countries that still facilitate the trading of paper certificates. These are especially used by retail investors who use them to be able to prove ownership of the shares if the broker goes bankrupt. According to a recent announcement, the largest settlement house in Europe, Euroclear (based in Brussels), will take over the processing of Irish paper certificates from the London Stock Exchange (Brady, 2019). However, the European Union will continue its efforts to dematerialize stock certificates, which are to be banned in the Member States from 2023 (Brady, 2019).

\section{Dematerialization of the contract}

The integration of the electronic means of communication with the formation of the contractual relations led to the appearance of the electronic contracts and to the phenomenon known as the dematerialization of the contract. Electronic contracts can be defined as contracts formed, signed, executed or notified by the use of electronic means of communication. Thus, in essence, the electronic contract is digital information distributed through the Internet network. Contract dematerialization generally refers to the use of electronic means of communication or the automation of contractual relations at any stage of a contract. As a result, new opportunities in contracting have arisen due to the development of electronic means of communication that can be linked to the establishment, execution, or communication of a contract. Currently, there are a multitude of electronic devices that can be used to communicate on the Internet, which means that these devices can also be used to communicate, sign, administer, execute and conclude electronic contracts.

The integration of IT\&C technology that led to the emergence of the Internet with business processes and public institutions has revolutionized the intra-organizational, interorganizational and relationship relationships between these entities and their interest holders (for example, customers, citizens, local communities, etc.). IT\&C technology has also revolutionized modern markets, with the Internet becoming the engine for the development of electronic markets that has led to the radical transformation of business models. Traditional commerce is based on physical stores and commercial employees, while ecommerce is based on digital trading platforms. Currently, much of the shopping is done via 
the internet, and goods and services are now available to buyers no matter the distance or time.

As e-commerce expanded, there was a need to dematerialize the contracts in order to allow for distance transactions without requiring the physical presence of the parties in the same place for signing the contract. Electronic contracts offer several obvious advantages, including cost reduction, increased efficiency, error reduction, and automation of procedures for establishing and executing contracts. Due to electronic contracts, ecommerce has been developed on a global scale, new business models based on a digital presence have been created, and it has been facilitated including contracting between companies that continue to apply traditional business models and their clients.

The proliferation of the use of electronic means of communication in the transactions in the business environment has created the need for international, regional and national organizations with legislative powers to be interested in the consequences on the contractual relations. Currently, many of the initiatives to facilitate contracting by electronic means have become laws. Conventions, legislative models, recommendations and indications have been introduced internationally. Moreover, most countries have amended their legislation in force to allow electronic contracting. However, legislative changes that impact on e-procurement are not designed to address the nature of e-contracts exclusively and do not contain a clear nomenclature for e-contracts. In fact, these new laws and regulations concern a much wider range of areas that have been affected by the adoption of electronic media for conducting commercial transactions and, by approaching at least tangentially electronic contracts, offer a solution to the legislative vacuum that prevents the adoption on a large scale of electronic contracting so far.

The United Nations was a pioneer in the field of electronic procurement. The UN, through the General Assembly or the Commission for the Law of International Trade (UNCITRAL), introduced various recommendations that were the basis for the development of laws for electronic contracts. These recommendations are worth mentioning: recommendations for governments and international organizations regarding the value of computer records in 1985, the 1996 e-commerce law model, the 2001 e-signature law model, and the convention for using electronic communication in international contracts. 2005. In particular, the 2005 convention represented an important legal document that set the global standards for electronic commerce legislation. In 2017, the UN also prepared the law model for transferable electronic records.

The regional organizations also took statutory measures. For example, the European Commission is one of the most active regional organizations in the field of electronic procurement. Over time, the Commission has enacted Directive 2000/31 / EC on electronic commerce, Directive 97/7 on distance contracts and Directive 1999/93 / EC on electronic signature. In addition, the European Commission has also issued a number of horizontal directives that also impact on electronic contracts, such as directives on the protection of personal data and copyright in the digital environment. In 2014, the European Parliament repealed Directive 1999/93 / EC by regulation on electronic identification and trust services for electronic transactions established in the territory of the Member States. The International Chamber of Commerce (ICC) has also issued several publications on electronic 
transactions including: the publication on the terms and conditions of electronic transactions in 2004 and the guide for using various forms of electronic commerce and establishing a framework for authenticating digital messages (GUIDEC since 2008). In 1997, the Organization for Economic Cooperation and Development adopted the guidelines for the development of legislation in the field of cryptography, which, although addressed to governments, in particular, covered certain aspects related to the use of cryptography in the case of electronic contracts. The OECD is also active in developing e-commerce guides and policies that aim to address certain issues related to e-contracts.

In addition to international and regional organizations, many states have taken legislative measures to overcome legal problems related to the use of electronic contracts and electronic commerce in general. For example, the US introduced UCITA - the law on transactions regarding digital information and UETA - the law on electronic transactions as models of laws to be adopted by each state. The US Congress also passed the law on the use of electronic signatures in national and global commerce in 2000. As the volume and geographical coverage of electronic commerce expand, more and more countries adopt laws on electronic commerce which, in inevitably, they also have an impact on electronic contracts. For example, the electronic contract, defined as a convention concluded by the use of electronic means of communication, has been legislated in Romania since 2002 by Law 35.

Currently, there are several types of electronic contracts, including an email contract (Tărchilă and Nagy, 2015). An email can be used to send an offer and to communicate the acceptance of an offer. In the basic form, it can be similar to a contract sent by mail because the seller sends an email in the buyer's mailbox managed by the Internet service provider that ensures that it reaches the destination. In face-to-face meetings, communication is immediate and instantaneous, which means that there is no clear distinction between when to send and when to receive or notify, which means that acceptance of contract terms becomes effective when communicated to the seller. All the parties are aware of the precise moment of the conclusion of the contract and do not face the problems encountered in the case of contracts communicated by post or email that may arrive late. In the distance contracts, there is a clear difference between the moment of sending and the moment of reception, and this delay creates uncertainties regarding the moment of the conclusion of the contract or even the validity of the contract. For example, an offer may no longer be valid when the acceptance confirmation comes from the buyer. In order to solve these problems, in most European countries it is considered that a contract was concluded when the seller received the acceptance for the offer, not the moment when the buyer sent the acceptance because, in essence, the email communication can be considered similar to the communication face to face.

In addition to e-mail contracts, there are three major types of e-contracts: shrinkwrap contracts, click-wrap contracts, and browse-wrap contracts (Kamantauskas, 2015). Shrink-wrap contracts are commonly used to protect software packages and, in their case, the terms and conditions are not visible to the consumer until the package is opened, the seal is broken, or the software is installed. This means that a consumer cannot read the terms and conditions before paying for the software, which raises legal issues regarding the validity of this type of contract. In most European countries, such a contract is considered valid as long 
as the buyer has the right to return the product or cancel the service after paying the price and unpacking the package if he does not agree with the contractual terms. In other cases, the contractual terms may lead to its invalidity, especially if the buyer has no means of expressing his / her consent other than to continue using the product or service.

The browse-wrap contracts refer to an agreement regarding the viewing, use or downloading of software from a website, in which the website owner mentions that a certain action such as downloading or using the website constitutes acceptance of a contract and will be considered as confirmation of acceptance regarding the terms and conditions of the contract. In most cases, browse-wrap contracts do not involve the sale of goods and services, but the download of certain digital programs or products or the use of a website. There are no visible means of consent for the terms and conditions of the contract; these are simply presented on the website. In this case, the main legal issue is raised by the fact that, in many cases, the user is not informed that he or she is entering into a legal relationship when doing a certain action and that it is not clear whether that action can be considered as a sign of acceptance of the terms and conditions. In general, it is considered that if the terms and conditions are not displayed and the user is not clearly informed that a certain action leads to the establishment of a contract, then this contract is not valid.

Click-wrap contracts refer to the case where a vendor uses a digital platform to display products and services with all relevant details. In this case, buyers can browse the website and if they are interested in a particular product, go to the product page for more information. After the buyer reads the information regarding the terms of payment, delivery and the possibility of exchange or return, he completes the order, when he has to give his agreement on these terms. The contract is concluded when the customer specifies that he agrees to the terms and conditions and completes the order. From a legal point of view, this type of contract is most similar to a traditional contract. The distinction between click-wrap contracts and browse-wrap contracts is that in click-wrap contracts the buyer is directly informed of the contractual terms and must express their agreement with them, whereas in browse-wrap contracts it is assumed that the user has read the terms and agreed with them since using or downloading the product. Regarding the legality of these contracts, the European directive on electronic commerce stipulates that the contractual terms should be provided in a form that allows the buyer to store the information and reproduce it as needed.

In order for an electronic contract to be valid, it is necessary for the parties to exchange a set of information intended to prevent the information asymmetry that may result from the seller having more transaction information than the buyer. The requirements regarding the information provided prior to the signing of the contract are seen as the main vehicle for consumer protection, an area in which the European Commission is very active if we consider that this principle is included in many directives. In the e-commerce directive, pre-contractual information is mainly viewed from a technical point of view. Article 10, for example, details the steps that the buyer must follow to sign a contract, the steps that the seller must follow to fulfill the contractual conditions and the technical means by which input errors can be identified and corrected, as well as the language that can be used to conclude a contract. In the Directive on distance contracts, the duties regarding consumer information are set out. According to Article 4, the necessary information includes: a) the identity of the 
supplier and, in the case of contracts requiring advance payment, his address; b) the main characteristics of the products or services; $c$ ) the price of the products or services together with the value of all taxes and commissions; d) the cost of delivery services, if any; e) the method of payment, delivery or performance of the services; f) the existence of the right to withdraw/renounce the contract; g) the cost of using the means of distance communication; h) the period for which the offer or price remains valid; i) as the case may be, the minimum duration of the contract when it involves the recurrent delivery of goods and services. The Consumer Rights Directive of 2011 aims to increase consumer confidence in e-commerce and, by Article 6, clearly sets out the information to be provided in the case of distance contracts which also include electronic contracts. For the most part, this information is similar to the ones required by the previous directives, but there are also some new precontractual information such as: a) the reminder of the legal guarantee regarding the conformity of the goods; b) the existence of after-sales services or a certain code of conduct that must be respected; c) the duration of the contract and the means by which it can cease; d) the need to pay financial guarantees or make certain deposits (if any); e) functionality and interoperability of digital products; f) the existence of alternative means of dispute resolution.

\section{Fintechs as an alternative to traditional banks}

The enthusiasm generated by fintech companies is almost general. In the press, these companies are presented as "disruptive", "revolutionary", armed with "digital weapons", which will "destroy" traditional barriers and financial institutions (World Economic Forum, 2017). Although fintech companies have penetrated financial markets rapidly, it is still unclear what their direct impact will be on banks and other financial institutions. The tension between stability and competition is at the heart of the whole debate about fintech and how the activity of these companies needs to be regulated. The crucial question is whether and when these fintech companies will replace banks and other existing financial institutions. Moreover, it is equally unclear whether this replacement will lead to an improvement of the competitive process, increasing the efficiency of the market which, in the past, was protected by high entry barriers, or will lead to market disintegration and financial instability.

Essentially, fintech refers to the use of technology to provide new or improved financial services. Part of the motivation that led to the emergence of fintech companies comes from the fact that although information technology has made everything (from computers to machines) cheaper and more functional, the unit cost of financial intermediation has not changed much in the last century. For example, according to Philippon (2015), the cost of financial intermediation in America has remained at about 2\% over the last 130 years. Therefore, one of the main promises of fintech is related to reducing the costs of financial services and improving the well-being of the clients of the financial industry.

According to the Financial Stability Board (FSB), fintech can be defined as "technology-based financial innovations that can result in new business models, applications, processes or products associated with a material effect on financial markets and institutions and on the provision of services" (Bank for International Settlements, 2018). 
This definition has also been adopted by BCBS, in particular, because it is large enough to take into account the fluidity of the development of the fintech domain. Although this area is extremely diverse, there are three main areas that fintech covers: a) executing transactions (payments, clearing and settlement, digital currencies, etc.); b) fund management (deposits, loans, investment management, capital raising, etc.); c) insurance (Favaretti, Calzolari and Pozollo, 2017). Much of fintech is based on blockchain technology, which is expected to have many benefits including: a) reduced costs for identifying parties involved in transactions; b) economies of scale and the collection and use of a large amount of data; c) transmission of information in a safer and cheaper way; and d) reducing verification costs (Thakor, 2019).

According to Consumers International (2017), fintech has so far gone through three major stages, and the first two stages that held until 2008 were characterized by the actions taken by traditional financial institutions, while the third stage that started in 2008 it is characterized by the action of some non-banking actors (see Table 4). According to a recent study, fintech companies specialized either in sectoral innovations in areas such as payment services, services for investment management or credit and savings services, or in a lifetime of support services for the financial sector such as data aggregation, services cloud, blockchain technology, customer identification and authentication services, Internet of Things technology etc. (see Table 5).

Table 3. The evolution of fintech from the beginning to the present

\begin{tabular}{|c|c|c|c|}
\hline Period & Fintech 1866 - 1967 & Fintech $1967-2008$ & Fintech 2008 - present \\
\hline \multirow{2}{*}{$\begin{array}{c}\text { Main } \\
\text { Technologies }\end{array}$} & Telegraph & $\begin{array}{c}\text { Electronic payments and } \\
\text { electronic settlement systems }\end{array}$ & \multirow{2}{*}{$\begin{array}{l}\text { Use of technology by new } \\
\text { actors to provide non- } \\
\text { intermediary financial } \\
\text { services directly to } \\
\text { customers }\end{array}$} \\
\hline & $\begin{array}{l}\text { The first transatlantic } \\
\text { cable }\end{array}$ & ATMs and online banking & \\
\hline Efects & $\begin{array}{l}\text { Rapid transmission of } \\
\text { financial information on } \\
\text { transactions and } \\
\text { payments }\end{array}$ & $\begin{array}{l}\text { Use of information technology } \\
\text { by traditional financial } \\
\text { institutions to increase the } \\
\text { quality of services and } \\
\text { products }\end{array}$ & $\begin{array}{l}\text { A new competitive } \\
\text { environment for financial } \\
\text { institutions }\end{array}$ \\
\hline
\end{tabular}

Source: Consumers International (2017).

Table 5 Services offered by fintech companies

\begin{tabular}{|c|c|c|c|c|}
\hline \multirow{6}{*}{$\begin{array}{c}\text { Sectoral } \\
\text { innovations }\end{array}$} & \multirow{2}{*}{$\begin{array}{l}\text { Lending, saving and } \\
\text { capital raising services }\end{array}$} & \multicolumn{2}{|c|}{$\begin{array}{l}\text { Payment, clearing and } \\
\text { settlement services }\end{array}$} & \multirow{2}{*}{$\begin{array}{c}\text { Investment } \\
\text { management } \\
\text { services }\end{array}$} \\
\hline & & Retail & Wholesale & \\
\hline & Crowdfunding & Mobile wallets & $\begin{array}{l}\text { Value transfer } \\
\text { systems }\end{array}$ & $\begin{array}{l}\text { High frequency } \\
\text { transactions }\end{array}$ \\
\hline & Credit markets & $\begin{array}{l}\text { Peer-to-peer } \\
\text { transactions }\end{array}$ & FX wholesale & $\begin{array}{c}\text { Social trading (copy } \\
\text { trading) }\end{array}$ \\
\hline & Mobile banks & \multirow{2}{*}{$\begin{array}{l}\text { Digital } \\
\text { currencies }\end{array}$} & \multirow{2}{*}{$\begin{array}{l}\text { Digital } \\
\text { exchange } \\
\text { platforms }\end{array}$} & $\begin{array}{c}\text { Electronic } \\
\text { transactions }\end{array}$ \\
\hline & $\begin{array}{l}\text { Creditworthiness } \\
\text { Assessment }\end{array}$ & & & $\begin{array}{c}\text { Automated } \\
\text { consultations }\end{array}$ \\
\hline \multirow{3}{*}{$\begin{array}{l}\text { Suport } \\
\text { services }\end{array}$} & \multicolumn{4}{|c|}{ Support Services Portals and data aggregators } \\
\hline & \multicolumn{4}{|c|}{ Ecosystems (infrastructure, open source, APIs) } \\
\hline & \multicolumn{4}{|c|}{ Applications for data management (predictive modeling, big data analysis) } \\
\hline
\end{tabular}




\begin{tabular}{|c|c|}
\hline \multirow{4}{*}{} & Technology based on distributed registers (blockchain, smart contracts) \\
\cline { 2 - 2 } & Security (customer identification and authentication) \\
\cline { 2 - 2 } & Cloud services \\
\cline { 2 - 2 } & Internet of Things technology or mobile technology \\
\hline Artificial intelligence (bots, automation, algorithms)
\end{tabular}

Source: BCBS and Bank for International Settlements (2018).

Global investments in fintech have grown considerably in recent years, from \$19.9 billion in 2014 to $\$ 39.4$ billion in 2017 (Fin-Tech Global, 2018). Moreover, in the first half of 2018 , the global fintech sector raised $\$ 41.7$ billion, which is much more than the value of investments in 2017. The studies conducted by Mansilla-Fernandez (2017) indicate a direct relationship between the level of investments in the fintech sector and certain characteristics of the national banking systems. For example, investments in fintech companies are higher in financially developed countries (taking into account the ratio of loans to GDP), and the use of electronic payments is more common in countries where there is a large percentage of the population with accounts open at different financial institutions (Mansilla-Fernandez, 2017). More importantly, investments in fintech companies are higher in countries with weaker (more concentrated) banking systems and in countries where interest on deposits is lower and interest on loans is higher (Mansilla-Fernandez, 2017). These correlations indicate that the best opportunities for the development of the fintech sector are in the most financially developed countries where a large part of the population has access to banking services and where banks enjoy a permissive competitive environment that allows them to extract higher incomes.

\section{Conclusions}

At this point, we can ask ourselves one last question: Can virtual money be considered cash? As we have shown above, they lack an essential quality of cash - anonymity, which derives from the possibility of objectifying cash. Most digital payment systems require the identification of both the buyer and seller either directly (name, account number, etc.) or indirectly (IP address). The only alternative that seems to promise anonymity is cryptocurrencies, but they have a controversial legal status at the moment, and it is clear that their transformation into legal means of payment will directly affect the anonymity of the parties involved in transactions. This should remind us of the true costs of a cashless company, a company in which all payments and transfers are recorded and can be tracked either by the state or by any other organization, leading to a company based on supervision.

An analysis of the fintech evolution to date and the main estimates made by experts shows that these companies will lead to increased competition in the financial markets, will offer in a much more efficient way the services and products that traditional financial institutions offer now, and they will even introduce new services and products (Mention, 2019). But fintech companies will not threaten the main functions performed by banks. In most cases, fintech companies are a more efficient way to carry out traditional activities, but banks are also positioned so that they can take advantage of technological innovations and change the way they provide their own services and products. 
It is important to note that the trend towards digitalization has changed the behavior and expectations of customers, a clear example being the widespread adoption of electronic payment solutions that increase the speed and safety of financial transactions. In fact, the digital transformation that takes place in the banking system has more to do with how customers adopt new technologies made available by banks, than with how technologies change the internal operations of banks. The biggest barrier to digitalisation is created by the need to fully understand the behavior of digital customers, how they make choices and the set of needs that banks have to cover. Given the abundance of technologies that can now be used in the banking system, banks must learn how to choose those technologies that best suit both the needs and digital skills of the customers, a need that is extremely relevant to the Romanian banking system which is facing a major discrepancy between customers who easily adopt the newest technologies and customers who prefer the traditional way of interacting (through branches) and cash payments. Thus, given the already existing studies which mostly concern only banks' perspective on the digitization process, it is necessary for future studies to investigate more closely the customer experience regarding the dematerialization of money, contracts and securities and digitization banking processes, with an emphasis on both the enrollment process and the entire customer relationship management process.

\section{Acknowledgments}

The present paper has been financially supported by the Academy of Romanian Scientists, Program No. 15/2019 "Strategies for Implementing Knowledge Economy in Romania".

The present paper has been financially supported by The Bucharest University of Economic Studies (ASE) „Dezvoltarea abilitaţilor antreprenoriale pentru doctoranzi si postdoctoranzi în domeniul stiinţelor economice” POCU/380/6/13/125015.

\section{References}

Allen, H., Hawkins, J. și Sato, S., 2001, „Electronic trading and its implications for financial systems" în Electronic finance: a new perspective and challenges, editat de Bank for International Settlements.

Baubeau, P., 2016, „Dematerialization and the cashless society: A look backward, a look sideward" în The Book of payments: historical and contemporary views on the cashless society, editat de Batiz-Lazo, B. Și Efthymiou, L., Londra: Palgrave Macmillan.

Brady, N., 2019, Paper share certs to get stay of execution from EU, The Times, [online] Available at www.thetimes.co.uk/article/paper-share-certs-to-get-stay-ofexecution-from-eu-sp7rpfv8j [accessed at 20.07.2019].

Bratianu, C. \& Orzea, I. (2013). “Emotional knowledge: the hidden part of the knowledge Iceberg”. In Janiunaite, B., Pundziene, A. \& Petraite, M. (Eds.). Proceedings of the $14^{\text {th }}$ European Conference on Knowledge Management, Kaunas University of Technology, Lithuania, 5-6 September 2013 (pp. 82-90). Reading: Academic Conferences and Publishing International.

Bratianu, C. (2018). "Intellectual capital research and practice: 7 myths and one golden rule”. Management \& Marketing. Challenges for the Knowledge Society, Vol. 13, Issue 2, pp. 859-879. 
Bratianu, C. \& Bejinaru, R. (2019). "The theory of knowledge fields: a thermodynamic Approach". Systems, Vol. 7, Issue 2, article 20, pp. 1-12.

Consumers International, 2017, Banking on the future: An exploration of fintech and the consumer interest, [online] Available at www.consumersinternational.org/media/ 154710/banking-on-the-future-full-report.pdf [accessed at 20.07.2019].

DTCC (2012). A proposal to fully dematerialize physical securities eliminating the costs and risks they incur, [online] Available at www.dtcc.com/ /media/Files/Downloads /WhitePapers/Dematerialize_Securities_July_2012.pdf [accessed at 20.07.2019].

European Commission, 2018, Banking sector: Value proposition of eIDAS-based eID, [online] Available at ec.europa.eu/cefdigital/wiki/display/EIDCOMMUNITY/Study +on+the+opportunities+and+challenges+of+eID+for+Banking?preview=/78548273 /78548264/20190206_eIDASeID_Banking.pdf [Accessed 12.07.2019].

Ferguson, N., 2009, The ascent of money: A financial history of the world, New York: Penguin Publishing Group.

Kamantauskas, P., 2015, Formation of click-wrap and browse-wrap contracts, Teises apzvalga Law Review, 1(2), 51-88.

Mansilla-Fernandez, J., 2017, Numbers, European Economy - Banks, Regulation, and the Real Sector, 3(2), 31-40.

Mention, A.-L., 2019, The future of fintech, Research-Technology Management, 62(4), 59-63.

Philippon, T., 2015, Has the US finance industry become less efficient? On the theory and measurement of financial intermediation, American Economic Review, 105(4), 14081438.

Pîrjan, A. and Petroșanu, D. M., 2008, Dematerialized monies - new means of payment, Romanian Economic Business Review, 3(2), 37-47.

Sachee, Z., 2016, Electronic trading \& the growth of automatic trading strategies, ECB Bond Market Contact Group [online] Available at www.ecb.europa.eu/paym/groups/ pdf/bmcg/160119/2016-01-19_Item_1.a.AutomatedTradingStrategies-dealer perspective.pdf?945d165db9fffc19b0ad4d92b60deb13 [accessed at 21.07.2019].

Tărchilă, P. și Nagy, M., 2015, Comparative approach of the electronic contract and classical Contract in teaching the content of the new Civil Code in Romania, Procedia - Social and Behavioral Sciences, 191, 464-468.

Thakor, A. V., 2019, Fintech and banking, [online] Available at ssrn.com/ abstract=3332550 [accessed at 23.07.2019].

Weatherford, J., 1998, The history of money, New York: Crown Business.

World Economic Forum, 2017, Beyond fintech: A pragmatic assessment of disruptive potential in financial services [online] Available at www3.weforum.org/docs/ Beyond_Fintech__A_Pragmatic_Assessment_of_Disruptive_Potential_in_Financial_Services.pdf [accessed at 20.07.2019].

*European Central Bank, 2019, Banknotes and coins circulation, [online] Available at: www.ecb.europa.eu/stats/policy_and_exchange_rates/banknotes+coins/circulation /html/index.en.html\# [accessed at 21.07.2019].

**fese.eu/statistics 